OPEN ACCESS

Edited by:

Marina Spinu,

University of Agricultural Sciences and

Veterinary Medicine of

Cluj-Napoca, Romania

Reviewed by:

Naouel Klibi,

Tunis El Manar University, Tunisia

Sudhakar G. Bhandare,

University of Nottingham,

United Kingdom

*Correspondence:

Ana Paula Guedes Frazzon

ana.frazzon@ufrgs.br

${ }^{\dagger}$ These authors have contributed equally to this work

Specialty section:

This article was submitted to Veterinary Infectious Diseases,

a section of the journal

Frontiers in Veterinary Science

Received: 14 September 2020 Accepted: 03 November 2020 Published: 04 December 2020

Citation:

Oliveira de Araujo G, Huff $R$ Favarini MO, Mann MB, Peters FB, Frazzon $J$ and Guedes Frazzon AP

(2020) Multidrug Resistance in

Enterococci Isolated From Wild

Pampas Foxes (Lycalopex gymnocercus) and Geoffroy's Cats (Leopardus geoffroyi) in the Brazilian Pampa Biome.

Front. Vet. Sci. 7:606377. doi: 10.3389/fvets.2020.606377

\section{Multidrug Resistance in Enterococci Isolated From Wild Pampas Foxes (Lycalopex gymnocercus) and Geoffroy's Cats (Leopardus geoffroyi) in the Brazilian Pampa Biome}

\author{
Gabriella Oliveira de Araujo ${ }^{1 t}$, Rosana Huff ${ }^{11}$, Marina Ochoa Favarini ${ }^{2}$, \\ Michele Bertoni Mann ${ }^{1}$, Felipe Bortolotto Peters ${ }^{2}$, Jeverson Frazzon ${ }^{3}$ and \\ Ana Paula Guedes Frazzon ${ }^{1 *}$
}

${ }^{1}$ Graduate Program in Agricultural and Environmental Microbiology, Institute of Basic Health Sciences, Federal University of Rio Grande Do Sul, Porto Alegre, Brazil, ${ }^{2}$ Institute for the Conservation of Neotropical Carnivores - "Pró-Carnivoros", Atibaia, Brazil, ${ }^{3}$ Institute of Food Science and Technology, Federal University of Rio Grande Do Sul, Porto Alegre, Brazil

Enterococci are ubiquitous microorganisms present in various environments and within the gastrointestinal tracts of humans and other animals. Notably, fecal enterococci are suitable indicators for monitoring antimicrobial resistance dissemination. Resistant bacterial strains recovered from the fecal samples of wild animals can highlight important aspects of environmental disturbances. In this report, we investigated antimicrobial susceptibility as well as resistance and virulence genes in fecal enterococci isolated from wild Pampas foxes (Lycalopex gymnocercus) $(n=5)$ and Geoffroy's cats (Leopardus geoffroyi) $(n=4)$ in the Brazilian Pampa biome. Enterococci were isolated from eight out of nine fecal samples and Enterococcus faecalis was identified in both animals. However, $E$. faecium and $E$. durans were only detected in Pampas foxes, while E. hirae was only detected in Geoffroy's cats. Antimicrobial susceptibility analysis showed resistance to rifampicin (94\%), erythromycin (72.6\%), ciprofloxacin/norfloxacin (40\%), streptomycin $(38 \%)$, and tetracycline (26\%). The high frequency of multidrug-resistant enterococci $(66 \%)$ isolated in this study is a matter of concern since these are wild animals with no history of therapeutic antibiotic exposure. The tetM/tetL and $m s r C / e r m B$ genes were detected in most tetracycline- and erythromycin-resistant enterococci, respectively. The gelE, ace, agg, esp, and clyA virulence genes were also detected in enterococci. In conclusion, our data suggest that habitat fragmentation and anthropogenic activities in the Pampa biome may contribute to high frequencies of multidrug-resistant enterococci in the gut communities of wild Pampas foxes and Geoffroy's cats. To the best of the authors' knowledge, this is the first report of antimicrobial-resistant enterococci in the Pampa biome.

Keywords: Enterococcus spp., pampa biome, wildlife animals, Pampas fox, Geoffroy's cat, multidrug-resistance, virulence factors, antibiotic resistance genes 


\section{INTRODUCTION}

Brazil hosts six terrestrial biomes, which include the Amazon, Atlantic Forest, Caatinga, Cerrado, Pampa, and Pantanal biomes. Notably, the Pampa biome covers 63\% of Rio Grande do Sul State and extend to Uruguay and the central region of Argentina (13 ). The fauna of the Brazilian Pampa biome consists of 83 native mammal species, of which some are endemic and/or considered endangered species. Among the mammal species, Geoffroy's cat (Leopardus geoffroyi) (Felidae) and the Pampas fox (Lycalopex gymnocercus) (Canidae) are listed as species of "least concern" in the IUCN Red List of Threatened Species $(4,5)$. The main factors contributing to the decline of these species are habitat destruction and hunting $(2,6,7)$. Farming activities have converted natural areas of the Brazilian Pampa into agricultural and grazing lands, with $\sim 48.7 \%$ of this biome now being used for plantation crops $(1,3)$.

This biome has been suffering constant disturbances due to anthropogenic impacts and the reduction of natural habitat has forced wild animals to live near human settlements, which has resulted in negative outcomes for wildlife conservation $(8,9)$. Pampas fox and Geoffroy's cat population density in Brazilian Pampa biome is 0.2 and $0.27 \mathrm{ind} / \mathrm{km}^{2}$, respectively $(10,11)$. Studies of wild canids and felids from the Pampa biome have shown that these animals exhibit adaptability in foraging based on prey availability, which can lead them to establish secondary food sources on farms. They are known to consume domestic vertebrates, fruit, insects, and carrion as well as to get food into the farms trash (12-14). In the past year, various studies have been published regarding habitat degradation and its effects on the wildlife and environment of the Pampa biome; however, studies evaluating the impact of multidrug-resistant bacteria on the wildlife in this biome remain scarce.

Enterococci are ubiquitous microorganisms found in water, soil, plants, and gastrointestinal tracts of wild animals, domestic animals, and humans (15-19). This ubiquitous distribution has been associated with phenotypic plasticity since they can tolerate a wide range of temperature and $\mathrm{pH}$ and grow in the presence of $6.5 \%$ sodium chloride $(\mathrm{NaCl})$ or $40 \%$ of bile salts (20). The genus Enterococcus comprises at least 50 species (21). Among these, E. faecalis is the predominant species in the gastrointestinal tracts of mammals, followed by E. faecium, E. durans, E. hirae, and E. mundtii (18).

Additionally, enterococci are considered opportunistic pathogens in susceptible hosts. They cause urinary tract, wound, and soft tissue infections as well as bacteremia $(22,23)$. Although enterococci are considered a common cause of nosocomial infections, they can also cause several diseases including bovine mastitis, endocarditis, septicemia, and diarrhea in dogs, cats, pigs, and rats (24). The treatment of enterococcal infections has been complicated by the emergence of antibiotic-resistant strains, which makes these infections an important public health concern. Resistance to different classes of antimicrobials is a hallmark of Enterococcus spp. since they are intrinsically resistant to $\beta$-lactams, cephalosporin, lincosamides, streptogramins, and aminoglycosides (25). Meanwhile, resistant strains are not restricted to clinically known species since such strains have been isolated from different environments, including wildlife $(15,17,19,24,26-30)$. Due to their remarkable ability to adapt to the environment, ubiquity in gut and to acquire antibiotic resistance determinants, enterococci have been employed as sentinel organisms for resistance to antimicrobials with Gram-positive activity.

Resistant bacterial strains recovered from wild animals can highlight important aspects of microbial interactions and environmental disturbances in wildlife $(31,32)$. Wild animals can be considered sentinels for the emergence and spread of antimicrobial-resistant bacteria in the environment. Therefore, the present study evaluated the presence of resistant enterococci in wild mammals aiming to detect previously unstudied variation in antimicrobial resistance distribution patterns in these animals. Additionally, to date, relatively few reports on antimicrobial resistance strains have been produced based on samples from wild canids and felids when compared to the number of reports on domestic animals. This difference could largely be explained by the migratory habits of some wild species and the difficulty of obtaining samples from wildlife. To the best of the authors' knowledge, this is the first study of antimicrobial resistance profiles and virulence genes in fecal enterococci isolated from wild Pampas foxes and Geoffroy's cats in the Brazilian Pampa biome.

\section{MATERIALS AND METHODS}

\section{Samples Collection}

Rectal swabs were collected from wild Pampas foxes $(n=5)$ and Geoffroy's cats $(n=4)$ (Figure 1). The animals were captured in two sites from Brazilian Pampa Biome, Rio Grande do Sul, Brazil. The first site was located near to Candiota city $\left(31^{\circ} 33^{\prime} 06.73^{\prime \prime} \mathrm{S}\right.$; $53^{\circ} 40^{\prime} 40.63^{\prime \prime} \mathrm{W}$ ), proximal to Jaguarão river, and characterized by intense agricultural, mining activity and roads; in this site, five samples were obtained. The second site was located near Arroio Grande city $\left(32^{\circ} 13^{\prime} 58.99^{\prime \prime} \mathrm{S} ; 53^{\circ} 05^{\prime} 11.75^{\prime \prime} \mathrm{W}\right)$, characterized by forest fragments and agricultural activities; in this site, four samples were obtained (Supplementary Table 1).

The capture, manipulation, and samples collections were authorized by Brazilian Institute of Environment and Renewable Natural Resources, IBAMA, Brasília, Brazil, and Chico Mendes Institute for Biodiversity Conservation (ICMBio). The protocol was approved by the Information Authorization System in Biodiversity (SISBIO) number 02001.007910 12006-32. The animals were captured with the assistance of Tomahawk traps and anaesthetized via intramuscular $(100 \mathrm{mg} / \mathrm{mL}$ of ketamine hydrochloride and $20 \mathrm{mg} / \mathrm{mL}$ of xylazine hydrochloride).

Rectal swabs were collected by veterinarians, all animals were clinically healthy (e.g., heart and respiratory rates and body temperature) and were classified according to gender and age group. Rectal swabs were collected from the perirectal area, stored in Stuart transport medium (Kasvi, Paraná, Brazil), and transported to our laboratory for microbiological analyses. After sample collection, the animals were returned to their habitats. All animals were in health conditions. 
A

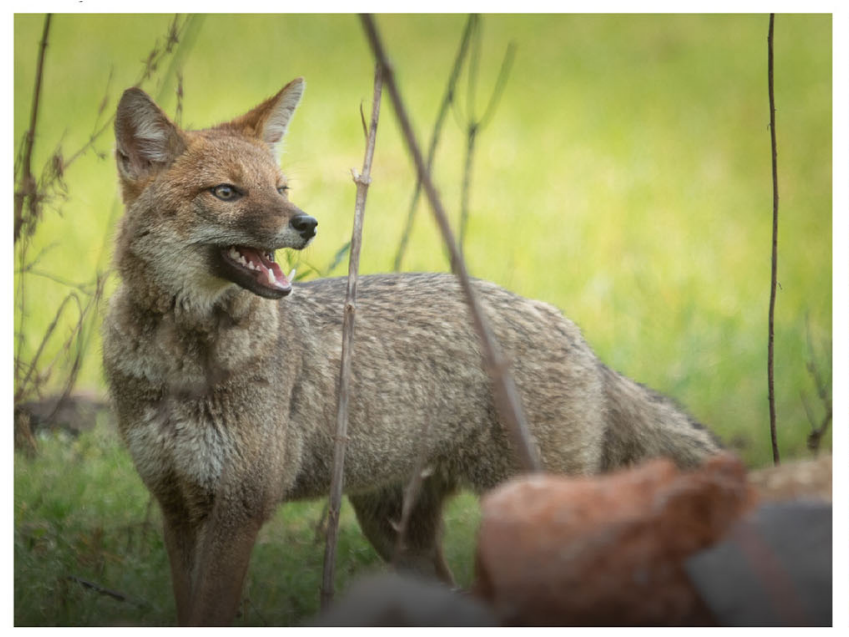

B

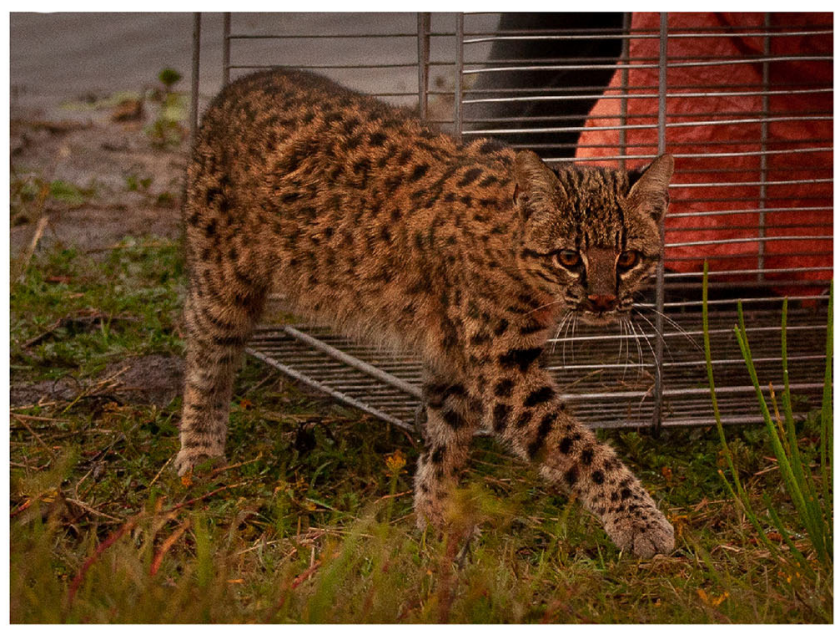

FIGURE 1 | Wild Pampas fox (Lycalopex gymnocercus) (A) and Geoffroy's cat (Leopardus geoffroyi) (B) during their capture in the Brazilian Pampa Biome. Source: Felipe Peters.

\section{Isolation and Identification of Enterococci}

Isolation of enterococci was performed as described previously (17). Rectal samples were inoculated in $9 \mathrm{~mL}$ of azide dextrose broth (Himedia, Mumbai, India) and incubated for $24 \mathrm{~h}$ at $37^{\circ} \mathrm{C}$. Aliquots of $1 \mathrm{~mL}$ were placed in $9 \mathrm{~mL}$ of saline water, and initial samples were further diluted 10 -fold to obtain a final dilution factor of $1 / 1,000$. From each dilution, $100 \mu \mathrm{L}$ was inoculated in brain heart infusion (BHI) agar plates (Himedia, Mumbai, India) supplemented with $6.5 \% \mathrm{NaCl}$.

Since enterococci are present in high concentrations in fecal samples, typically between $10^{5}$ and $10^{7} \mathrm{CFU} / \mathrm{g}$, we randomly selected 10 colonies from each fecal sample. Phenotypic criteria (size/volume, shape, color, Gram staining, catalase production), and bile esculin reaction were used to separate the enterococci group and the non-enterococcal strains. Selected pure colonies were stored at $-20^{\circ} \mathrm{C}$ in a $10 \%(\mathrm{w} / \mathrm{v})$ solution of skim milk (Difco, Sparks, MD, USA) and 10\% (v/v) glycerol (Neon Comercial Ltda).

Bacterial species identification was performed by matrixassisted laser desorption and ionization time-of-flight mass spectrometry method (MALDI-TOF) technique applied to Enterococcus (33). MALDI-TOF analysis was performed using a LT Bruker microflex mass spectrometer (Bruker Daltonik $\mathrm{GmbH}$ ) and spectra were automatically identified using BrukerBioTyper ${ }^{\mathrm{TM}} 1.1$ software. The identification by MALDITOF MS is based on the score value released by the equipment. A higher or similar 2.3 value indicates that the identifications of genus and species are reliable. $2.0-2.29$ show that the genus is reliable and the species is probable. 1.7-1.99 values indicate that the identification of genus is probable.

\section{Antimicrobial Susceptibility Testing}

Antimicrobial susceptibility of all strains was determined by Kirby-Bauer disk diffusion method, according to Clinical and Laboratory Standards Institute (34). Twelve antibiotics were tested: ampicillin $10 \mu \mathrm{g}$ (AMP), vancomycin $30 \mu \mathrm{g}$ (VAN), erythromycin $15 \mu \mathrm{g}$ (ERY), tetracycline $30 \mu \mathrm{g}$ (TET), ciprofloxacin $5 \mu \mathrm{g}$ (CIP), norfloxacin $10 \mu \mathrm{g}$ (NOR), nitrofurantoin $300 \mu \mathrm{g}$ (NIT), chloramphenicol $30 \mu \mathrm{g}$ (CHL), gentamicin $120 \mu \mathrm{g}$ (GEN), linezolid $30 \mu \mathrm{g}$ (LNZ), rifampicin 5 $\mu \mathrm{g}$ (RIF), and streptomycin $300 \mu \mathrm{g}$ (STR). Reference strain $E$. faecalis ATCC 29212 was used as control.

Intermediate and resistant-strains were included in a single category as resistant-strains. Strains were classified as single (SR), double (DR) or multidrug-resistant (MDR) phenotype when showed resistance for one, two, and three or more antimicrobial classes, respectively (35).

\section{Detection of Resistance and Virulence Genes}

Genomic DNA was extracted by a physicochemical method as previously described (36). The presence of resistance and virulence genes commonly observed in clinical and environmental enterococci was tested by PCR (Table 1). The resistance-related genes evaluated were: ermB (which encodes a ribosomal methylase that mediates macrolides, lincosamides and type $\mathrm{B}$ streptogramins resistance); $m s r \mathrm{C}$ (which encodes for a macrolide and streptogramin $\mathrm{B}$ efflux pump); tet $\mathrm{M}$ and tetS (which encodes for tetracycline resistance via a ribosomal protection protein mechanism); and tet $\mathrm{L}$ (which encodes for tetracycline resistance via efflux pumps proteins). As well the virulence genes tested were: ace (adhesin to collagen of $E$. faecalis); cylA (cytolysin); agg (aggregation substance); gelE (gelatinase); and esp (enterococcal surface protein).

Amplifications were carried out in a total volume of $25 \mu \mathrm{L}$ containing: $100 \mathrm{ng}$ of template DNA, $1 \mathrm{X}$ reaction buffer (Ludwig Biotechnology), $0.4 \mu \mathrm{M}$ of each primer (Ludwig Biotechnology), $1.5 \mathrm{mM} \mathrm{MgCl} 2,200 \mu \mathrm{M}$ of dNTPs (Ludwig Biotechnology), 
TABLE 1 | Primers used in the PCR reactions carried out for detection of resistance and virulence genes.

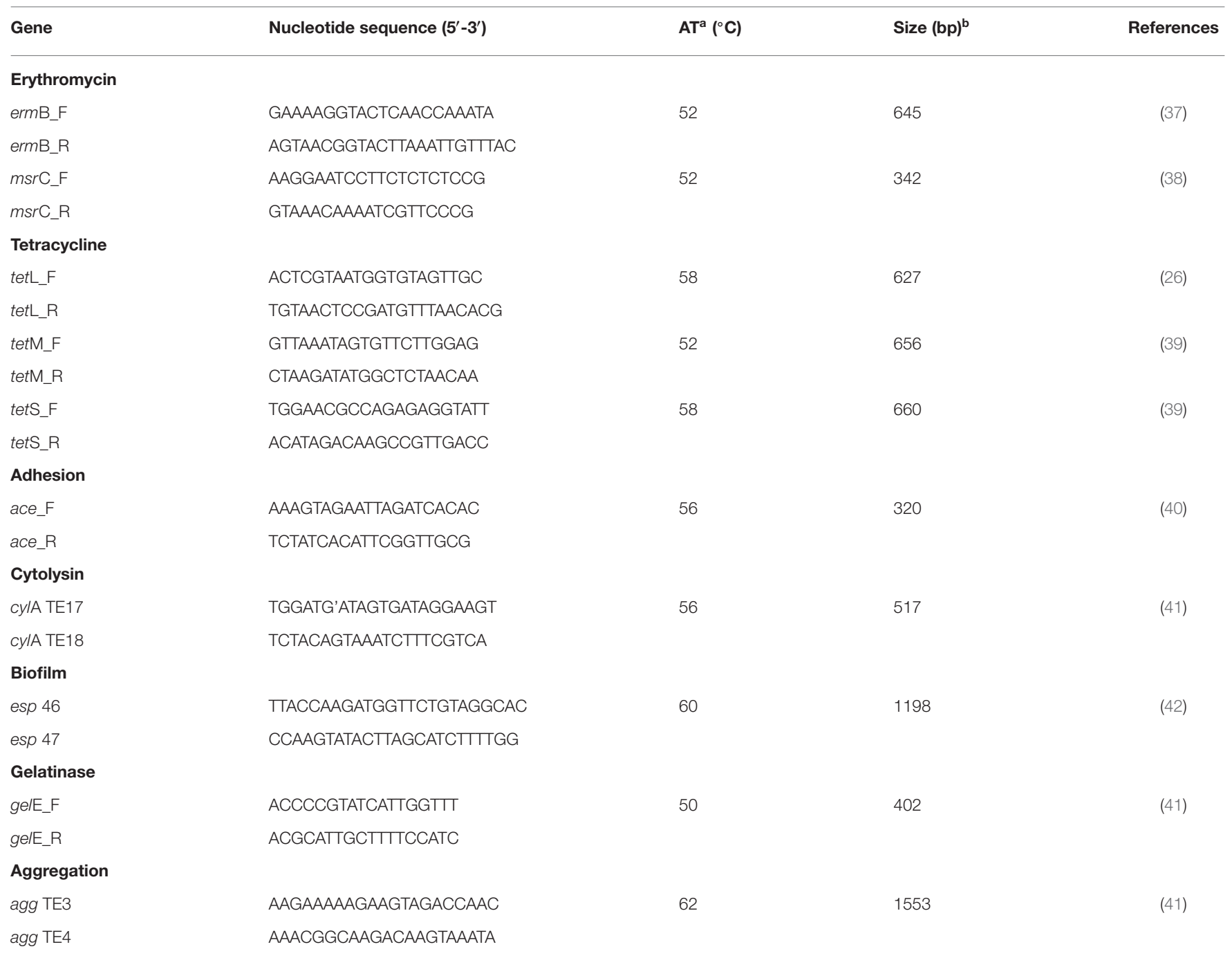

${ }^{a} A T$, annealing temperatures; ${ }^{b} b p$, base pair.

$1 \mathrm{U}$ Taq DNA polymerase (Ludwig Biotechnology), and MilliQ water. PCR amplifications were performed in the conventional thermocycler (Applied Biosystems 2720 Thermal Cycler) according to the following program: $94^{\circ} \mathrm{C}$ for $5 \mathrm{~min}$ followed by 35 cycles of $94^{\circ} \mathrm{C}$ for $1 \mathrm{~min}$, appropriate annealing temperature for each primer for $1 \mathrm{~min}$, extension at $72^{\circ} \mathrm{C}$ for $1 \mathrm{~min}$, and a final extension at $72^{\circ} \mathrm{C}$ for $5 \mathrm{~min}$. The DNA fragments amplified were analyzed in $1.5 \%(\mathrm{w} / \mathrm{v})$ agarose gels stained with $\mathrm{SYBR}^{\circledR}$ Safe DNA Gel, and visualized on a photo-documenter.

\section{RESULTS}

In order to not overestimate the data referring to species distribution and antimicrobial susceptibility profile, strains isolated from the same animal with similar phenotypic and genotypic characteristics, which could indicate clonal strains, were grouped, generating a total of 50 strains, 30 from Pampas foxes and 20 from Geoffroy's cats. The number of isolates per wild animal ranged from 5 (samples PF3, PF4 and GC1) to 9 (sample GC3).

\section{Isolation and Identification of Enterococci}

Enterococci were isolated from eight out of nine fecal samples. Furthermore, 50 Enterococcus spp. strains were isolated and characterized of wild Pampas fox and Geoffroy's cat from the Brazilian Pampa biome, including E. faecalis (64\%; $n=32), E$. faecium $(22 \% ; n=11)$, E. hirae $(10 \% ; n=5)$, and E. durans $(4 \%$; $n=2)$.

The species distribution between wild Pampas foxes and Geoffroy's cats are shown on Table 2. Changes in the composition of Enterococcus species were detected in both animals. E. faecalis was the most frequent species in fecal samples of both animals; however, E. faecium and E. durans were isolated only in Pampas fox and E. hirae just in Geoffroy's cat. 


\section{Antimicrobial Susceptibility Profile}

All enterococci isolated from wild canids and felids were tested for antimicrobial resistance, and almost all strains (98\%, $n$ $=49$ ) were resistant to at least one evaluated antimicrobial agent (Table 3). Only one E. hirae isolated from Geoffroy's cat was susceptible to all antimicrobials tested. The highest frequency was found for rifampicin $(94 \% ; n=47)$, followed by erythromycin (72\%; $n=36)$, ciprofloxacin/norfloxacin $(40 \% ; n$ $=20)$, streptomycin (38\%; $n=19)$, and tetracycline $(26 \% ; n=$ 13). Resistance to nitrofurantoin $(18 \% ; n=9)$; gentamycin $(14 \%$, $n=7)$, and chloramphenicol $(4 \% ; n=2)$, was noted in less frequency. No strains showed a resistance profile to ampicillin, linezolid and vancomycin.

The most remarkable result to emerge from the data is that a high frequency $(66 \% ; n=33)$ of MDR strains isolated from wild canids and felids from Brazilian Pampa biome (Table 3).

TABLE 2 | Distribution of Enterococcus species among wild Pampas fox and Geoffroy's cat.

\begin{tabular}{lllllll}
\hline & & \multicolumn{4}{c}{ Number of species isolated } & \\
\cline { 3 - 5 } Pampas fox & & E. faecalis & E. faecium & E. hirae & E. durans & Total \\
\hline \multirow{2}{*}{ PF1 } & 4 & 1 & 0 & 1 & 6 \\
& PF2 & 2 & 5 & 0 & 0 & 7 \\
& PF3 & 2 & 3 & 0 & 0 & 5 \\
& PF4 & 2 & 2 & 0 & 1 & 5 \\
& PF5 & 7 & 0 & 0 & 0 & 7 \\
& GC1 & 5 & 0 & 0 & 0 & 5 \\
& GC2 & 0 & 0 & 0 & 0 & 0 \\
& GC3 & 9 & 0 & 0 & 0 & 9 \\
& GC4 & 1 & 0 & 5 & 0 & 6 \\
\hline & Total & $32(64)$ & $11(22)$ & $5(10)$ & $2(4)$ & $50(100)$
\end{tabular}

The percentages of double and MDR strains isolated from wild Pampas fox (30\%; $n=9$ and $63.33 \% ; n=19)$ were similar to wild Geoffroy's cat $(20 \% ; n=4$ and $70 \% ; n=14)$. Of the $33 \mathrm{MDR}$ strains, $15(45.45 \%)$ were resistant to four or more antimicrobials, it is important to highlight that one E. faecalis strain isolated from wild Pampas fox showed resistance to seven antimicrobials tested (ciprofloxacin; chloramphenicol; erythromycin; streptomycin; nitrofurantoin; rifampicin; tetracycline) (Table 4).

\section{Frequency of Antimicrobial Resistance and Virulence Related Genes}

The resistance genes were investigated only in phenotypically resistant erythromycin and tetracycline strains (Table 5). Of the 36 erythromycin- resistant, four (11.11\%) harbored ermB and nine $(25 \%) \mathrm{msrC}$ genes. Among the 13 tetracycline-resistant enterococci, tet $\mathrm{L}$ and tet $\mathrm{M}$ genes were found in 7 (53.85\%) strains. None strain was positive to tetS gene.

All strains were tested for the presence of enterococci commonly associated virulence genes. The Table 6 shows the results of gelE, cylA, esp, ace, and agg genes. The highest frequencies of virulence genes were found in E. faecalis and $E$. faecium. The gelE (62\%; $n=31)$ and ace $(48 \% ; n=24)$ showed elevated prevalence among these species. The agg gene $(22 \% ; n$ $=11$ ) was recorded only on $E$. faecalis strains. Otherwise, esp and cylA genes were observed in just one E. faecium and E. hirae strains, respectively.

\section{DISCUSSION}

\section{Isolation and Identification of Enterococci}

Relatively few studies have reported enterococci isolated from wild canids and felids such as red foxes (43), Iberian wolves, and Iberian lynx $(44,45)$. The results of the present study corroborate with previous results showing that E. faecalis, E. faecium, E. hirae, and E. durans are commonly encountered in the fecal samples of

TABLE 3 | Antimicrobial resistance profiles among enterococci isolated from fecal samples of wild Pampas fox and Geoffroy's cat.

\begin{tabular}{|c|c|c|c|c|c|c|c|c|c|c|c|}
\hline \multirow{2}{*}{ Strains (n) } & \multicolumn{8}{|c|}{ Number $(\%)$ of resistant strains ${ }^{a}$} & \multicolumn{3}{|c|}{ Profiles $^{b}$} \\
\hline & ERY & CIP/NOR & RIF & STR & GEN & NIT & CHL & TET & SR & DR & MDR \\
\hline \multicolumn{12}{|l|}{ Pampas fox } \\
\hline E. faecalis (17) & $13(76.47)$ & $7(41.18)$ & $16(94.12)$ & $7(41.18)$ & $4(23.53)$ & $3(17.65)$ & $1(5.88)$ & $2(11.76)$ & $1(5.88)$ & $5(29.41)$ & $11(64.70)$ \\
\hline E. faecium (11) & 7 (63.64) & $4(36.36)$ & $11(100)$ & $4(36.36)$ & 0 & 1 (9.09) & 0 & $4(36.36)$ & $1(9.09)$ & $4(36.36)$ & $6(54.55)$ \\
\hline E. durans (2) & $2(100)$ & 0 & $2(100)$ & $1(50)$ & $1(50)$ & 0 & 0 & $1(50)$ & 0 & 0 & $2(100)$ \\
\hline Subtotal (30) & $22(73.33)$ & $11(36.67)$ & $29(96.67)$ & $12(40)$ & $5(16.67)$ & $4(13.33)$ & $1(3.33)$ & $7(23.33)$ & $2(6.67)$ & $9(30)$ & $19(63.33)$ \\
\hline \multicolumn{12}{|l|}{ Geoffroy's cat } \\
\hline E. faecalis (15) & $12(80)$ & $9(60)$ & $15(100)$ & $3(20)$ & $2(13.33)$ & $1(6.67)$ & $1(6.67)$ & $1(6.67)$ & 0 & $4(26.67)$ & $10(66.67)$ \\
\hline E. hirae (5) & $2(40)$ & 0 & $3(60)$ & $4(80)$ & 0 & $4(80)$ & 0 & $5(100)$ & $1(20)$ & 0 & $4(80)$ \\
\hline Subtotal (20) & $14(70)$ & $9(45)$ & $18(90)$ & $7(35)$ & $2(10)$ & $5(25)$ & $1(5)$ & $6(30)$ & $1(5)$ & $4(20)$ & $14(70)$ \\
\hline Total (50) & $36(72)$ & $20(40)$ & 47 (94) & $19(38)$ & $7(14)$ & $9(18)$ & $2(4)$ & $13(26)$ & $3(6)$ & $13(26)$ & 33 (66) \\
\hline
\end{tabular}

a Antimicrobials: ERY, erythromycin; CIP, ciprofloxacin; NOR, norfloxacin; RIF, rifampicin; STR, streptomycin; GEN, gentamicin; NIT, nitrofurantoin; CHL, chloramphenicol; TET, tetracycline.

${ }^{b}$ Profiles: SR, single-resistance; DR, double-resistance; MDR, multidrug-resistance. 
TABLE 4 | Antimicrobial resistance phenotypic profile of Enterococcus sp. isolated from fecal samples of wild Pampas fox and Geoffroy's cat.

\begin{tabular}{|c|c|c|c|c|}
\hline \multirow{2}{*}{ Profile $^{a}$} & \multirow{2}{*}{ Antimicrobials $^{\mathrm{b}}$} & \multirow{2}{*}{ Species } & \multicolumn{2}{|c|}{ Number of resistances } \\
\hline & & & $\mathbf{P F}^{\mathrm{c}}$ & $G^{d}$ \\
\hline \multirow[t]{3}{*}{ SR } & RIF & E. faecalis & 1 & \\
\hline & & E. faecium & 1 & \\
\hline & TET & E. hirae & & 1 \\
\hline \multirow[t]{6}{*}{ DR } & ERY/RIF & E. faecalis & 3 & 3 \\
\hline & & E. faecium & 2 & \\
\hline & STR/RIF & E. faecium & 1 & \\
\hline & CIP-NOR/RIF & E. faecalis & 1 & 1 \\
\hline & & E. faecium & 1 & \\
\hline & NIT/RIF & E. faecalis & 1 & \\
\hline \multirow[t]{23}{*}{ MDR } & CIP-NOR/ERY/RIF & E. faecalis & 3 & 4 \\
\hline & & E. faecium & 1 & \\
\hline & $\mathrm{CIP} / \mathrm{STR} / \mathrm{RIF}$ & E. faecalis & 1 & \\
\hline & CIP/ERY/TET & E. faecium & 1 & \\
\hline & $\mathrm{CIP} / \mathrm{CH} / \mathrm{RIF}$ & E. faecalis & & 1 \\
\hline & ERY/STR/TET & E.durans & 1 & \\
\hline & ERY/GEN/RIF & E. faecalis & 1 & \\
\hline & & E. durans & 1 & \\
\hline & ERY/STR/RIF & E. faecium & 1 & \\
\hline & STR/GEN/RIF & E. faecalis & 1 & \\
\hline & CHL/ERY/RIF & E. faecalis & & 1 \\
\hline & CIP/ERY/GEN/RIF & E. faecalis & & 1 \\
\hline & CIP/STR/GEN/RIF & E. faecalis & & 2 \\
\hline & CIP/ERY/STR/RIF & E. faecalis & 1 & 1 \\
\hline & STR/NIT/TET/NOR & E. hirae & & 1 \\
\hline & STR/NIT/TET/RIF & E. hirae & & 1 \\
\hline & ERY/STR/GEN/RIF & E. faecalis & 1 & \\
\hline & ERY/STR/TET/RIF & E. faecium & 1 & \\
\hline & ERY/STR/NIT/TET/RIF & E. faecium & 1 & \\
\hline & & E. faecalis & 1 & 1 \\
\hline & & E. hirae & & 2 \\
\hline & CIP/ERY/STR/GEN/RIF & E. faecalis & 1 & \\
\hline & CIP/CHL/ERY/STR/NIT/TET/RIF & E. faecalis & 1 & \\
\hline
\end{tabular}

a SR, single-resistance; $D R$, double-resistance; MDR, multidrug-resistance.

${ }^{b}$ Antimicrobials: ERY, erythromycin; CIP, ciprofloxacin; NOR, norfloxacin; RIF, rifampicin; STR, streptomycin; GEN, gentamicin; NIT, nitrofurantoin; CHL, chloramphenicol; TET, tetracycline.

${ }^{c} P F$, Pampas fox (L. gymnocercus).

${ }^{d} \mathrm{GC}$, Geoffroy's cat (L. geoffroyi).

wild and domestic canids and felids (31, 43-47). However, when we verified the distribution of enterococci in Pampas foxes and Geoffroy's cats, we observed a higher frequency of E. faecalis than those previously reported for wild red foxes, Iberian lynx, and Iberian wolves $(44,45)$. Moreover, our results are comparable to those of domestic canids and felids $(31,46,47)$ since frequencies of E. faecalis (64.9\%), E. faecium (18.2\%), and E. durans (6.5\%) were detected. This minor disagreement is supported by the fact that the distribution of enterococci may vary according to individual characteristics (e.g., species, age, and sex), habitat (e.g., seasonal variations and diet), and the geographic distribution of the animals (20).

Enterococcal species prevalence varied according to the host species studied. Although these species occupy the same area of the Biome, several types of foods are available to them. Geoffroy's cat and Pampas fox are considered generalist omnivores that opportunistically feed on a wide variety of foods. Pampas fox has a diet dominated by animal prey, mainly wild mammals, insects, while the Geoffroy cat feeds mainly on rodents and hares, and also remains of fish and frogs alongside reptiles and birds $(48,49)$. Thus, the distribution of Enterococcus species among hosts observed in the present study can be justified by the availability of the animals' food, since enterococcal species have been isolated from mammals, birds, fish, insects, and reptiles (20).

Notably, it was not possible to isolate enterococci from one of Geoffroy's cat fecal samples. Previously, Santestevan et al. (50) and Layton et al. (51) also sought to isolate enterococci from mammalian fecal samples and were unsuccessful.

\section{Antimicrobial Susceptibility Profile}

The results of this study are consistent with previous studies, which found high rates of resistance to erythromycin (65\%), ciprofloxacin (59.5\%), and tetracycline (36.5\%) in fecal enterococci isolates from wild mammals, including wolves and foxes (31). Some reports have detected enterococci resistant to tetracycline and erythromycin in wild Iberian wolves, Iberian lynx, and red foxes in Portugal (43-45). Additionally, domestic canids and felids also harbored antimicrobial-resistant enterococci $(47,52,53)$.

While MDR enterococci strains have previously been observed in enterococci isolated from wild mammals, their resistance levels were not as high as those detected here. In the present study, $66 \%$ of MDR was observed for wild canids and felids from the Brazilian Pampa biome. The high frequency of MDR strains may be associated with the proximity of these animals to human activities since they are sentinel species (i.e., indicators of danger to the environment). It is commonly known that wild canids and felids are indifferent to the presence of humans and often share the same environment. Our results are in line with those of Nowakiewicz et al. (54), who observed a high frequency of E. faecalis strains (44\%) among wild mammalian carnivores in Poland. On the other hand, our data are six times higher than those detected by Dec et al. (30). According to $\mathrm{Hu}$ et al. (55), MDR bacteria are more commonly associated with environmental contamination than naturally occurring genes. Moreover, studies of wild foxes and carnivorous mammals revealed positive correlations with environmental pollution and the abundance of resistant bacteria in samples, thereby highlighting the selective pressures that 
TABLE 5 | Distribution of erythromycin- and tetracycline-resistance genes in the enterococci isolated from wild Pampas Fox and Geoffroy's cat.

\begin{tabular}{|c|c|c|c|c|c|c|c|c|}
\hline & \multirow{3}{*}{ Strains } & \multicolumn{7}{|c|}{ Number $(\%)$ of strains positive for resistance genes } \\
\hline & & \multicolumn{3}{|c|}{ Erythromycin } & \multicolumn{4}{|c|}{ Tetracycline } \\
\hline & & $\mathbf{R}^{\star}$ & ermB & msrC & $\mathbf{R}^{\star}$ & tetM & tetL & tetS \\
\hline \multirow[t]{4}{*}{ Pampa fox } & E. faecalis & 13 & 0 & $5(38.46)$ & 2 & 0 & 0 & 0 \\
\hline & E. faecium & 7 & 0 & $3(42.86)$ & 4 & 0 & 0 & 0 \\
\hline & E. durans & 2 & $1(50)$ & $1(50)$ & 1 & $1(100)$ & $1(100)$ & 0 \\
\hline & Subtotal & 22 & $1(4.55)$ & $9(40.91)$ & 7 & 1 (14.29) & $1(14.29)$ & 0 \\
\hline \multirow[t]{4}{*}{ Geoffroy's cat } & E. faecalis & 12 & 1 (8.33) & 0 & 1 & $1(100)$ & $1(100)$ & 0 \\
\hline & E. hirae & 2 & $2(100)$ & 0 & 5 & $5(100)$ & $5(100)$ & 0 \\
\hline & Subtotal & 14 & $3(21.43)$ & 0 & 6 & $6(100)$ & $6(100)$ & 0 \\
\hline & Total & 36 & $4(11.11)$ & $9(25)$ & 13 & 7 (53.85) & $7(53.85)$ & 0 \\
\hline
\end{tabular}

${ }^{*}$ Resistant strains.

TABLE 6 | Number (\%) of virulence genes among enterococci isolated from wild Pampas Foxes and Geoffroy's cat.

\begin{tabular}{|c|c|c|c|c|c|c|}
\hline \multirow[b]{2}{*}{ Virulence genes } & \multicolumn{3}{|c|}{ Pampas fox } & \multicolumn{2}{|c|}{ Geoffroy's cat } & \multirow[b]{2}{*}{ Total (\%) } \\
\hline & E. faecalis $(n=17)$ & E. faecium $(n=11)$ & E. durans $(n=2)$ & E. faecalis $(n=15)$ & E. hirae $(n=5)$ & \\
\hline ge/E & 12 (70.59) & $5(45.45)$ & 0 & 14 (93.33) & 0 & $31(62)$ \\
\hline cylA & 0 & 0 & 0 & 0 & $1(20)$ & $1(2)$ \\
\hline esp & 0 & 1 (9.09) & 0 & 0 & 0 & $1(2)$ \\
\hline ace & 12 (70.59) & 7 (63.64) & 0 & 5 (33.33) & 0 & $24(48)$ \\
\hline agg & 7 (41.18) & 0 & 0 & $4(26.67)$ & 0 & $11(22)$ \\
\hline
\end{tabular}

human activities and environmental disturbances exert on the microbial communities of wildlife $(31,54)$.

The elevated frequency of resistant and MDR enterococci observed in the fecal samples of wild Pampas foxes and Geoffroy's cats might be associated with anthropogenic activities. Agriculture and livestock are the main economic activities in the Brazilian Pampa and represents a source of food for billions of people and animals (mainly cattle and sheep). Since 1998, many drugs have been prohibited from being used as growth promoters in Brazil. In livestock, antimicrobials such as amoxicillin, erythromycin and tetracycline are used by veterinarians to treat bacterial infections (56). Despite bringing benefits to production, the use of antimicrobials in animals has fostered the emergence and spread of antimicrobial resistance. Antibiotics and/or antibiotic-resistant bacteria can be secreted with animal urine and feces and contaminate the environments (soils, surface waters, and ground waters) and species inhabiting these environments (57). In the presence of environmental concentrations of antibiotics, bacteria face a selective pressure leading to a gradual increase in the prevalence of resistance. The association of antibiotic resistance genes in mobile genetic elements is also an important factor for spreading and persistence of antimicrobial resistance in the environment (58). It is important to highlight that the impact created by the presence of antimicrobial agents in the environment and the frequency with which these resistance genes are transferred remains a subject of academic and practical debate. Our results suggest that the impacted environment occupied by Pampas foxes and Geoffroy's cats - with intense agricultural and livestock activities in the sampling area-possibly contributed to the selection of resistant bacteria in the environment and subsequent acquisition of resistant strains by these mammals. Despite anthropogenic activities, the presence of antibiotic-resistant strains in wild animals may also be associated with the environmental resistome, which is composed of genes that naturally occur in the environment (59). One example is the genes associated with the expression of efflux pumps, which protect cells against toxic molecules such as heavy metals, expelling them to the external environment and leading to antimicrobial resistance (60).

\section{Frequency of Antibiotic Resistance Genes}

The erm $\mathrm{B}$ and $m s r \mathrm{C}$ genes, conferring resistance to macrolides, were present in 11.11 and $25 \%$ of isolates, respectively. The low frequency of erm $\mathrm{B}$ genes detected in the present study is congruent with the results obtained in previous studies conducted on Enterococcus strains isolated from wild animals $(17,18,30,50)$, as in regarding to $m s r C$ gene (28). Additionally, we detected the presence of the $m s r C$ gene not only in $E$. faecium but also in E. durans and E. faecalis. Although the msrC gene is considered an intrinsic gene to E. faecium, some studies have 
noted the presence of this gene in other Enterococcus species such as E. hirae and E. faecalis $(30,38)$.

In the present study, tet $\mathrm{L}$ and tet $\mathrm{M}$ genes were detected in tetracycline-resistant enterococci strains. Previous findings of enterococci in wild animals such as Iberian wolves and Iberian lynx also harbored those genes in tetracycline-resistant strains $(44,45)$. Some erythromycin- and tetracycline-resistant strains did not amplify for the tested gene and may carry other antibiotic resistance genes such as erm A, C, D, E, F, G, Q, msrA/B, other tet-group genes, and the poxtA gene for tetracycline-resistance (61). Our results point to the notion that other reported genes could be associated with erythromycin-resistant enterococci isolated from Pampas foxes and Geoffroy's cats. Furthermore, whole-genome sequencing (WGS) of these enterococci might be useful in identifying additional mechanisms associated with resistance profiles.

Antibiotic resistance genes commonly reside on transmissible plasmids or on other mobile genetic elements, which allow the horizontal transfer of these genes between strains. The tet $\mathrm{M}$, tet $\mathrm{L}$, and erm $\mathrm{B}$ genes are carried out by mobile genetic elements, such as transposons ( $\operatorname{Tn} 916, \operatorname{Tn} 1545$, and $\operatorname{Tn} 917)$, conjugative transposons or plasmids (58). The association of these genes in mobile genetic elements might be an important factor for spreading of antimicrobial resistant enterococci in wild Pampas foxes and Geoffroy's cats.

\section{Frequency of Virulence-Related Genes}

The results of the present study suggest that enterococci obtained from wild Pampas foxes and Geoffroy's cats harbored virulence genes. Moreover, E. faecalis was the most common species to carry virulence factors. These results are congruent with previous studies highlighting E. faecalis as the most common enterococcal species associated with infections, which accounts for $80-90 \%$ of infections. The presence of virulence factors in clinical enterococci strains is associated with persistent and difficult-to-treat infections. However, some authors consider the occurrence of these genes in non-clinical strains as a common characteristic that increases their ability to colonize hosts, which improves the survival and proliferation of the strains. Since the ubiquity of enterococci across a wide range of environments was initiated by the establishment of these bacteria in either abiotic surfaces or live tissues, their colonization can be facilitated by the expression of virulence genes that likely contribute to the persistence of enterococci in the environment (20).

One limitation of our study is the low number of animals sampled, which is due to the difficulty of obtaining samples from wildlife. For example, a study conducted in an anthropogenic area of the Brazilian Pampa during a 1 year period, 12 Geoffroy's cat individuals were captured (62). Notably, capturing and handling wild animals requires specialized equipment, the consideration of animal welfare concerns (regardless of the reason for capture), and the efforts of experienced biologists and wildlife technicians to plan and study suitable capture methods. In light of these points, the number of animals evaluated in the present study should be well-considered. Despite its relatively small sample size, this study demonstrated the importance of conducting research related to the impact of human activities on the Brazilian Pampa biome.

In conclusion, this study observed the presence of resistant Enterococcus strains in wild Pampas foxes and Geoffroy's cats from the Brazilian Pampa biome. The presence of MDR enterococci in fecal samples from these wild animals suggests that habitat fragmentation and the impact of anthropogenic activities on the environment might contribute to the occurrence of resistant strains in the microbial gut communities of these animals. Furthermore, these animals may contribute to the spread of resistant strains between different ecosystems. To the best of our knowledge, this is the first study of resistant commensal enterococci recovered from wild animals in the Brazilian Pampa biome. We believe that our research will serve as a foundation for future studies on the Pampa biome.

\section{DATA AVAILABILITY STATEMENT}

The original contributions presented in the study are included in the article/Supplementary Materials, further inquiries can be directed to the corresponding author.

\section{ETHICS STATEMENT}

The animal study was reviewed and approved by Instituto Brasileiro do Meio Ambiente e dos Recursos Naturais Renováveis (IBAMA), and Chico Mendes Institute for Biodiversity Conservation (ICMBio). The protocol was approved by Information Authorization System in Biodiversity (SISBIO) no. 02001.007910 12006-32.

\section{AUTHOR CONTRIBUTIONS}

GO, JF, and AG designed the study. FP and MF carried out the sampling work. GO, RH, MM, JF, and AG analyzed the data and drafted the manuscript. All authors have read and approved the final manuscript.

\section{FUNDING}

This research was supported by CNPq-Nos. 407886/2018-4, 302574/2017-4, and 303251/2014-0 and the PROAP-CAPES.

\section{ACKNOWLEDGMENTS}

We thank the Conselho Nacional de Desenvolvimento Científico e Tecnológico do Brasil (CNPq), Coordenação de Aperfeiçoamento de Pessoal de Nível Superior (CAPES); Federal University of Rio Grande do Sul and Lutheran University of Brazil.

\section{SUPPLEMENTARY MATERIAL}

The Supplementary Material for this article can be found online at: https://www.frontiersin.org/articles/10.3389/fvets. 2020.606377/full\#supplementary-material 


\section{REFERENCES}

1. Roesch LFW, Vieira FCB, Pereira VA, Schünemann AL, Teixeira IF, Senna AJT, et al. The Brazilian Pampa: a fragile biome. Diversity. (2009) 1:18298. doi: 10.3390/d1020182

2. Andrade BO, Bonilha CL, Overbeck GE, Vélez-Martin E, Rolim RG, Bordignon SAL, et al. Classification of South Brazilian grasslands: implications for conservation. Appl. Veg. Sci. (2018) 22:168-84. doi: 10.1111/avsc.12413

3. Ministério do Meio Ambiente [MMA]. Pampa - Conhecimentos $e$ Descobertas. (2020). Available online at: https://www.mma.gov.br/biomas/ pampa (accessed September 4, 2020).

4. International Union for Conservation of Nature [IUCN]. Leopardus geoffroyi. (2020). Available online at: https://www.iucnredlist.org/species/ 15310/50657011 (accessed September 4, 2020).

5. International Union for Conservation of Nature [IUCN]. Lycalopex gymnocercus. (2020). Available online at: https://www.iucnredlist.org/species/ 6928/85371194 (accessed September 4, 2020).

6. Espinosa CC, Galiano D, Kubiak BB, Marinho JR. Medium- and large-sized mammals in a steppic savanna area of the brazilian pampa: survey and conservation issues of a poorly known fauna. Braz. J. Biol. (2016) 76:739. doi: 10.1590/1519-6984.12714

7. Valmorbida I, Cherman MA, Jahn DS, Guedes JVC. Abundance and diversity in the melolonthidae community in cultivated and natural grassland areas of the Brazilian Pampa. Environ. Entomol. (2018) 47:106471. doi: 10.1093/ee/nvy109

8. Gothwal R, Shashidhar T. Antibiotic pollution in the environment: a review. Clean Soil Air Water. (2015) 43:479-89. doi: 10.1002/clen.201300989

9. Hassell JM, Begon M, Ward MJ, Fèvre EM. Urbanization and disease emergence: dynamics at the wildlife-livestock-human interface. Trends Ecol. Evol. (2017) 32:55-67. doi: 10.1016/j.tree.2016.09.012

10. Almeida LB, Queirolo D, Oliveira TG, Beisiegel BM. Avaliação do risco de extinção do gato-do-mato Leopardus geoffroyi (d'Orbigny \& Gervais 1844) no Brasil. Bio Brasil. (2013) 3:84-90. Available online at: https://www.icmbio.gov. br/portal/images/stories/biodiversidade/fauna-brasileira/avaliacao-do-risco/ carnivoros/gato-do-mato_leopardus_geoffroyi.pdf (accessed November,19 2020).

11. Queirolo D, Kasper CB, Beisiegel BM. Avaliação do risco de extinção do graxaim-do-campo Lycalopex gymnocercus (G. Fischer 1814) no Brasil. Bio Brasil. (2013) 3:172-8. Available online at: https://www.icmbio.gov.br/ portal/images/stories/biodiversidade/fauna-brasileira/avaliacao-do-risco/ carnivoros/graxaim-do-campo_lycalopex_gymnocercusi.pdf (accessed November,19 2020).

12. Manfredi C, Lucherini M, Canepuccia AD, Casanave EB. Geographical variation in the diet of Geoffroy'S cat (Oncifelis geoffroyi) in Pampas grassland of Argentina. J. Mammal. (2004) 85:1111-5. doi: 10.1644/BWG-133.1

13. Canepuccia AD, Martinez MM, Vassallo AI. Selection of waterbirds by Geoffroy's cat: effects of prey abundance size and distance. Mamm. Biol. (2007) 72:163-73. doi: 10.1016/j.mambio.2006.07.003

14. Canel D, Scioscia NP, Denegri GM, Kittlein YM. The diet of the Pampas fox (Lycalopex gymnocercus) in the province of Buenos Aires. Mastozool Neotrop. (2016) 23:359-70. Available online at: https://bibliotecadigital.exactas.uba.ar/ collection/paper/document/paper_03279383_v23_n2_p359_Canel (accessed November, 19 2020).

15. Poeta P, Costa D, Sáenz Y, Klibi N, Ruiz-Larrea F, Rodrigues J. et al. Characterization of antibiotic resistance genes and virulence factors in faecal enterococci of wild animals in Portugal. Zoonoses Public Health. (2005) 52:396-402. doi: 10.1111/j.1439-0450.2005.00881.x

16. Byappanahalli MN, Nevers MB, Korajkic A, Staley ZR, Harwood VJ. Enterococci in the environment. Microbiol. Mol. Biol. Rev. (2012) 76:685706. doi: 10.1128/MMBR.00023-12

17. Prichula J, Pereira RI, Wachholz GR, Cardoso LA, Tolfo NCC, Santestevan NA, et al. Resistance to antimicrobial agents among enterococci isolated from fecal samples of wild marine species in the southern coast of Brazil. Mar. Pollut. Bull. (2016) 105:51-7. doi: 10.1016/j.marpolbul.2016.02.071

18. García-Solache M, Rice B. The enterococcus: a model of adaptability to its environment. Clin. Microbiol. Rev. (2019) 32:2. doi: 10.1128/CMR.00058-18

19. Huff R, Pereira RI, Pissetti C, de Araújo AM, d'Azevedo PA, Frazzon J, et al. Antimicrobial resistance and genetic relationships of enterococci from siblings and non-siblings Heliconius erato phyllis caterpillars. PeerJ. (2020) 8:e8647. doi: $10.7717 /$ peerj. 8647

20. Lebreton F, Willems RJL, Gilmore MS. Enterococcus diversity origins in nature and gut colonization. In: Gilmore MS, Clewell DB, Ike Y, Shankar N, editors. Enterococci: From Commensals to Leading Causes of Drug Resistant Infection. New York, NY: Eye and Ear Infirmary (2014). p. 1-82.

21. List of prokaryotic names with standing in nomenclature [LPSN]. Genus Enterococcus. Available online at: https://lpsn.dsmz.de/genus/enterococcus (accessed November, 19 2020).

22. Prieto AMG, Van Schaik W, Rogers MRC, Coque TM, Baquero F, Corander J, et al. Global emergence and dissemination of Enterococci as nosocomial pathogens: attack of the clones? Front. Microbiol. (2016) 7:788. doi: $10.3389 /$ fmicb. 2016.00788

23. Selleck EM, van Tyne D, Gilmore MS. Pathogenicity of Enterococci. Microbiol. Spectr. (2018) 7:GPP3-00532018. doi: 10.1128/microbiolspec.GPP3-0053-2018

24. Torres C, Alonso CA, Ruiz-Ripa L, León-Sampedro R, Del Campo R, Coque TM. Antimicrobial resistance in Enterococcus spp. of animal origin. Microbiol. Spectr. (2018) 6:ARBA-0032-2018. doi: 10.1128/9781555819804.ch9

25. Miller WR, Munita JM, Arias CA. Mechanisms of antibiotic resistance in enterococci. Expert Rev. Anti Infect. Ther. (2014) 12:1221-36. doi: 10.1586/14787210.2014.956092

26. Frazzon APG, Gama BA, Hermes V, Bierhals CG, Pereira RI, Guedes AG, et al. Prevalence of antimicrobial resistance and molecular characterization of tetracycline resistance mediated by tet $(\mathrm{M})$ and tet $(\mathrm{L})$ genes in Enterococcus spp. isolated from food in Southern Brazil. World. J. Microbiol. Biotechnol. (2010) 26:365-70. doi: 10.1007/s11274-009-0160-x

27. Cassenego APV, d'Azevedo PA, Ribeiro AML, Frazzon J, Van Der Sand ST, Frazzon APG. Species distribution and antimicrobial susceptibility of enterococci isolated from broilers infected experimentally with Eimeria spp and fed with diets containing different supplements. Braz. J. Microbiol. (2013) 42:480-8. doi: 10.1590/S1517-83822011000200012

28. Grassotti TT, Zvoboda DD, Xavier LCF, De Araújo AJG, Pereira RI, Soares RO, et al. Antimicrobial resistance profiles in Enterococcus spp. isolates from fecal samples of wild and captive black capuchin monkeys (Sapajus nigritus) in South Brazil. Front. Microbiol. (2018) 9:2366. doi: 10.3389/fmicb.2018.02366

29. Novais C, Campos J, Freitas AR, Barros M, Silveira E, Coque TM, et al. Water supply and feed as sources of antimicrobial-resistant Enterococcus spp. in aquacultures of rainbow trout (Oncorhyncus mykiss) Portugal. Sci. Total Environ. (2018) 625:1102-12 doi: 10.1016/j.scitotenv.2017.12.265

30. Dec M, Stepień-Pyśniak D, Gnat S, Fratini F, Urban-Chmiel R, Cerri D, et al. Antibiotic susceptibility and virulence genes in Enterococcus isolates from wild mammals living in Tuscany Italy. Microb. Drug Resist. (2019) 26:505-19. doi: 10.1089/mdr.2019.0052

31. Tripathi V, Cytryn E. Impact of anthropogenic activities on the dissemination of antibiotic resistance across ecological boundaries. Essay. Biochem. (2017) 61:11-21. doi: 10.1042/EBC20160054

32. Mo SS, Urdahl AM, Madslien K, Sunde M, Nesse LL, Slettemeås JS, et al. What does the fox say? Monitoring antimicrobial resistance in the environment using wild red foxes as an indicator PLoS ONE. (2018) 13:e0198019. doi: 10.1371/journal.pone.0198019

33. Sauget $M$, Valot B, Bertrand $X$, Hocquet D. Can MALDI-TOF mass spectrometry reasonably type bacteria? Trends Microbiol. (2017) 25:44755. doi: 10.1016/j.tim.2016.12.006

34. Clinical and Laboratory Standards Institute [CLSI]. Performance Standards for Antimicrobial Susceptibility Testing. 28th ed. Wayne, PA: CLSI (2018).

35. Schwarz S, Silley P, Simjee S, Woodford N, van Duijkeren E, Johnson AP, et al. Editorial: assessing the antimicrobial susceptibility of bacteria obtained from animals. J. Antimicrob. Chemother. (2010) 65:601-4. doi: 10.1093/jac/dkq037

36. Depardieu F, Perichon B, Courvalin P. Detection of the van alphabet and identification of enterococci and staphylococci at the species level by multiplex PCR. J. Clin. Microbiol. (2004) 42:5857-60. doi: 10.1128/JCM.42.12.5857-5860.2004

37. Sutcliffe J, Grebe T, Tait-Kamradt A, Wondrack L. Detection of erythromycinresistant determinants by PCR. Antimicrob. Agents Chemother. (1996) 40:2562-6. doi: 10.1128/AAC.40.11.2562

38. Werner G, Hildebrandt B, Witte W. The newly described $m s r C$ gene is not equally distributed among all isolates of 
Enterococcus faecium. Antimicrob. Agents Chemother. (2001)

Aarestrup FM, Agerso Y, Gerner-Smidt P, Madsen M, Jensen LB. Comparison of antimicrobial resistance phenotypes and resistance genes in Enterococcus faecalis and Enterococcus faecium from humans in the community broilers and pigs in Denmark. Diagn. Microbiol. Infect. Dis. (2000) 37:12737. doi: 10.1016/S0732-8893(00)00130-9

40. Mannu L, Paba A, Daga E, Comunian R, Zanetti S, Duprè I, et al. Comparison of the incidence of virulence determinants and antibiotic resistance between Enterococcus faecium strains of dairy animal and clinical origin. Int. J. Food Microbiol. (2003) 88:291-304. doi: 10.1016/S0168-1605(03)00191-0

41. Eaton TJ, Gasson MJ. Molecular screening of Enterococcus virulence determinants and potential for genetic exchange between food and medical isolates. Appl. Environ. Microbiol. (2001) 67:1628-35. doi: 10.1128/AEM.67.4.1628-1635.2001

42. Shankar V, Baghdayan AS, Huycke MM, Lindahl G, Gilmore MS. Infection-derived Enterococcus faecalis strains are enriched in esp a gene encoding a novel surface protein. Infect. Immun. (1999) 67:193200. doi: 10.1128/IAI.67.1.193-200.1999

43. Radhouani H, Igrejas G, Gonçalves A, Pacheco R, Monteiro R, Sargo $\mathrm{R}$, et al. Antimicrobial resistance and virulence genes in Escherichia coli and enterococci from red foxes (Vulpes vulpes). Anaerobe. (2013) 23:826. doi: 10.1016/j.anaerobe.2013.06.013

44. Gonçalves A, Igrejas G, Radhouani H, Correia S, Pacheco R, Santos T, et al. Antimicrobial resistance in faecal enterococci and Escherichia coli isolates recovered from Iberian wolf. Lett. Appl. Microbiol. (2013) 56:26874. doi: 10.1111/lam.12044

45. Gonçalves A, Igrejas IG, Radhouani H, Santos T, Monteiro R, Pacheco R, et al. Detection of antibiotic resistant enterococci and Escherichia coli in free range Iberian Lynx (Lynx pardinus). Sci. Total Environ. (2013) 456-457:1159. doi: 10.1016/j.scitotenv.2013.03.073

46. Kataoka Y, Umino Y, Ochi H, Harada K, Sawada T. Antimicrobial susceptibility of enterococcal species isolated from antibiotic-treated dogs and cats. J. Vet. Med. Sci. (2014) 76:1399-402. doi: 10.1292/jvms.13-0576

47. Ben Said L, Dziri R, Sassi N, Lozano C, Ben Slama K, Ouzari I, et al. Species distribution antibiotic resistance and virulence traits in canine and feline enterococci in Tunisia. Acta Vet. Hung. (2017) 65:17384. doi: 10.1556/004.2017.018

48. Farías AA, Kittlein MJ. Small-scale spatial variability in the diet of Pampa foxes (Pseudalopex gymnocercus) and human-induced changes in prey base. Ecol. Res. (2008) 23:543-55. doi: 10.1007/s11284-007-0407-7

49. Trigo F, Tirelli FP, Machado LF, Peters FB, Indrusiak CB, Mazin FD, et al. Geographic distribution and food habits of Leopardus tigrinus and L. geoffroyi (Carnivora Felidae) at their geographic contact zone in southern Brazil. Stud. Neotrop. Fauna Environ. (2013) 23:56-67. doi: 10.1080/01650521.2013.774789

50. Santestevan NA, Zvoboda DA, Prichula J, Pereira RI, Wachholz GR, Cardoso LA, et al. Antimicrobial resistance and virulence factor gene profiles of Enterococcus spp. isolates from wild Arctocephalus australis (South American fur seal) and Arctocephalus tropicalis (Subantarctic fur seal). World J. Microbiol. Biotechnol. (2015) 31:1935-46. doi: 10.1007/s11274-015-1938-7

51. Layton BA, Walters SP, Lam LH, Boehm A. Enterococcus species distribution among human and animal hosts using multiplex PCR. J. Appl. Microbiol. (2010) 109:539-47. doi: 10.1111/j.1365-2672.2010.04675.x
52. Aslantaş Ö, Tek E. Isolation of ampicillin and vancomycin resistant Enterococcus faecium from dogs and cats. Kafkas Univ. Vet. Fak. Derg. (2019) 25:263-9. doi: 10.9775/kvfd.2018. 20912

53. Iseppi R, Di Cerbo A, Messi P, Sabia C. Antibiotic resistance and virulence traits in vancomycin-resistant enterococci (VRE) and extendedspectrum $\beta$-lactamase/ampc-producing (esbl/ampc) Enterobacteriaceae from humans and pets. Antibiotics. (2020) 9:1-14. doi: 10.3390/antibiotics 9040152

54. Nowakiewicz A, Zieba $\mathrm{P}$, Gnat $\mathrm{S}$, Trościańczyk A, Osińska M, Łagowski D, et al. A significant number of multi-drug resistant Enterococcus faecalis in wildlife animals; long-term consequences and new or known reservoirs of resistance? Sci. Total Environ. (2020) 705:135830. doi: 10.1016/j.scitotenv.2019.135830

55. HuY, Gao GF, Zhu B. Antibiotic resistome: gene flow in environments animals and human beings. Front. Med. (2017) 11:161-8. doi: 10.1007/s11684-017-0531-x

56. Rabello RF, Bonelli RR, Penna BA, Albuquerque JP, Souza RM, Cerqueira AMF. Antimicrobial resistance in farm animals in Brazil: an update overview. Animals. (2020) 10:1-43. doi: 10.3390/ani10040552

57. Kummerer K. Antibiotics in the aquatic environment-a review-part I. Chemosphere. (2009) 75:417-34. doi: 10.1016/j.chemosphere.2008.11.086

58. Hegstad K, Mikalsen T, Coque TM, Werner G, Sundsfjord A. Mobile genetic elements and their contribution to the emergence of antimicrobial resistant Enterococcus faecalis and Enterococcus faecium. Clin. Microbiol. Infect. (2010) 16:541-54. doi: 10.1111/j.1469-0691.2010. 03226.x

59. Pal C, Bengtsson-Palme J, Kristiansson E, Larsson DGJ. The structure and diversity of human animal and environmental resistomes. Microbiome. (2016) 4:1-15. doi: 10.1186/s40168-016-0199-5

60. Allen HK, Donato J, Wang HH, Cloud-Hansen KA, Davies J, Handelsman J. Call of the wild: antibiotic resistance genes in natural environments. Nat. Rev. Microbiol. (2010) 8:251-9. doi: 10.1038/nrmicro2312

61. Antonelli A, D’Andrea MM, Brenciani A, Galeotti CL, Morroni G, Pollini S, et al. Characterization of poxtA a novel phenicol-oxazolidinone-tetracycline resistance gene from an MRSA of clinical origin. J. Antimicrob. Chemother. (2018) 73:1763-9. doi: 10.1093/jac/dky088

62. Tirelli FP. Análises ecológicas de duas espécies de felídeos (Leopardus Geoffroyi e L. Colocolo) em áreas antropizadas da savana Uruguaia (master's thesis). Porto Alegre Pontifícia Universidade Católica de Porto Alegre, Porto Alegre, Brazil (2017).

Conflict of Interest: The authors declare that the research was conducted in the absence of any commercial or financial relationships that could be construed as a potential conflict of interest.

Copyright (C) 2020 Oliveira de Araujo, Huff, Favarini, Mann, Peters, Frazzon and Guedes Frazzon. This is an open-access article distributed under the terms of the Creative Commons Attribution License (CC BY). The use, distribution or reproduction in other forums is permitted, provided the original author $(s)$ and the copyright owner(s) are credited and that the original publication in this journal is cited, in accordance with accepted academic practice. No use, distribution or reproduction is permitted which does not comply with these terms. 